\title{
A Cleansing Crisis?
}

Sergei A. Karaganov

\author{
Sergei A. Karaganov, Doctor of History \\ National Research University-Higher School of Economics, Moscow, Russia \\ Dean of the Faculty of World Economy and International Affairs; \\ Council on Foreign and Defense Policy, Russia \\ Honorary Chairman of the Presidium \\ SPIN RSCI: 6020-9539 \\ ORCID: 0000-0003-1473-6249 \\ ResearcherID: K-6426-2015 \\ Scopus AuthorID: 26025142400 \\ Tel.: + 7495 771-3252; +7 495 772-9590 Ext. 22306 \\ E-mail: skaraganov@hse.ru \\ Address: Office 103, 17 Malaya Ordynka Str., Moscow 119017, Russia \\ DOI: $10.31278 / 1810-6374-2021-19-1-32-42$
}

This article precedes a series of studies aimed at analyzing major crises of the 20th and early 21st centuries and the experience of resolving them. Such a collection will be useful for finding solutions in the current situation. ${ }^{1}$

\footnotetext{
Dor many years experts from the Russian Council on Foreign $\gamma$ and Defense Policy talked about the inevitability of a largescale crisis or a new stage of the 2008 crisis. Many sensed it. The growing feeling of trouble, the expectation of a disaster and even a war literally hung in the air. The pandemic triggered an avalanche and made it quite distinct.
}

\footnotetext{
The study was carried out with the financial support of the Russian Foundation for Basic Research and the Expert Institute for Social Research as part of Project 20-011-31821 "Mega Tendencies of World Political and Economic Development in the Context of a Global Systemic Crisis: Models and Strategies for Russia." Other materials prepared under this project at available in Russian at: https://globalaffairs.ru/issues/2021/1/
} 
At the beginning of 2020 and during the first mass lockdown, government officials and many economists foresaw the likelihood of a "rebound" (beginning of a recovery) by the end of 2020 and by all means in 2021. However, we relied on more pessimistic-or rather realistic-expectations. The crisis will be long, severe, dangerous, and comparable to the Great Depression of the 1930s, which the world basically did not overcome until World War II. We hope that humanity will overcome the current cataclysm without a big war that may become the end of its history.

\section{WHAT IS HAPPENING?}

In this article I will try to describe the current crisis as we are going through its epicenter. A complete description is hardly possible not only because the crisis is just unfolding, but also because of the lack of real information about what is happening, or to be more precise, because there is a flood of false or often manipulated information. Its producers (there are more of them by several orders of magnitude than in any of the previous periods) are in confusion. So, I will have to rely not on knowledge, but rather on intuition, which can be misleading. Yet I will risk my reputation. In fact, I will not be doing this for the first time, and the time we are living in is risky anyway.

Whatever the parallels with the previous crises, the current one is quite unique. It really is, primarily because several things happened at the same time: the economic tsunami caused by the pandemic; the final collapse of the international economic and political orders established after World War II, and the West's (seeming) "victory" in the Cold War; elements of a civilizational crisis in the West, which has dominated the world for centuries; international political and strategic stability is rapidly declining, conflicts are multiplying, the threat of their escalation into a big war is growing, and the credibility of concepts devised before this complex crisis is waning visibly. There is also an intellectual failure.

Naturally, there is a pandemic itself and the inability of poor countries and many states to cope with it. But for all its danger to human life and health, this trouble can hardly compare to the terrible plagues humanity has experienced before. Its significance has been 
exaggerated by the information onslaught that has gone out of control and also by attempts of the ruling elites in a considerable number of countries to deflect attention from their past failures and retain power. The pandemic is used as a substitute for war, distracting and justifying. In many ways, the situation is, indeed, similar to a big war, but so far without millions of victims. And since this is a war-like situation, it is necessary to act by the "à la guerre comme à la guerre" principle, that is, to do what we have not had the courage to do so far.

So, this creates a picture of an almost comprehensive, systemic and multi-dimensional crisis with expectedly unpredictable consequences. Let me start with the economic aspects that lie closest to the surface.

The crisis will by all means exacerbate dramatically the growing inequality and the sense of injustice ingrained in the modern economic system, and further reduce the already shrunk middle class in developed countries. Everyone will become poorer, but especially poor countries.

One of the fundamental contradictions, if not vices, of the contemporary world is becoming quite obvious: the modern model of capitalism, based on the endless and stimulated growth of consumption, has outlived itself. Even if (and when) the current concern about climate change yields real results, this will not solve the underlying problem. People in developed countries and those aspiring to join them consume thoughtlessly and unreasonably much, well above normal human needs. But how to limit the growth of consumption when billions of people are poor and, most importantly, when they see, owing to the media, how rich people and countries live? Moreover, they also see a picture which is obviously embellished for commercial or political reasons. This issue is quite acute in Russia as well.

It seems that the problem of environmental pollution is being drowned in empty talking. In fact, Europe, the main mouthpiece for this issue, is simply trying to shift the burden to others by imposing tariffs on energy-intensive goods, although, objectively, the main pollutants are excessive consumers, that is, rich countries and individuals. At the end of 2020, when this article was written, there were dismally few signs of attempts to seriously rethink the development model both in 
our country and in the world, which many, including myself, hoped for during the pandemic outbreak.

\section{DEMOCRACY AND ITS PROBLEMS}

China and Asia as a whole are rather winning the current fierce competition, but in general everyone is losing. The preliminary results of the crisis are mounting social tension in societies and new cases of mass hunger in a number of regions. And as a result, instability is growing both within and between many states, including those near our borders. Many governments will fall. Humanity is taking another step back from the ideals of eternal peace and responsible global governance. And it is hardly comforting that the "liberal economic order" created at Bretton Woods, which spread to the whole world after 1991 and gave powerful advantages to its initiators through a system of economic regimes and rapidly weakening institutions such as the WTO, the IMF and others, is crumbling rapidly. It is being replaced by the economic and political (we will discuss this later) law of the jungle. There are no signs of a new balanced and fair system. And there is at least a decade of chaos ahead.

The current crisis is likely to spur a number of emerging sociopolitical trends. Efficient authoritarian states are better at coping with the epidemic (although in fairness, there are also many inefficient authoritarian ones). The truth carefully concealed by liberal political correctness that was dominant for many decades is coming to the surface.

Democracy is a way to manage only rich societies and only in the absence of severe external stress.

All democracies have always perished. Greek republics gave way to despotism, the Roman Republic became an empire, Italian medieval republics turned into monarchies, the Novgorod Republic fell, and the French one was replaced by an empire. The February Democratic Revolution in Russia led to the emergence of a totalitarian system. Almost all of Europe's democracies surrendered to Hitler. Such a fate, apparently, awaited Great Britain too, if it had not been for the help of the United States protected throughout its history by oceans and weak neighbors, and the fact that Germany attacked the USSR whose people 
were controlled by a rigid totalitarian system and displayed unique readiness for self-sacrifice.

Current democratic regimes brought to relatively poor states are crumbling, failing and giving way to authoritarian regimes, unless their democratic structure is supported from the outside, as in the European Union's periphery countries. But the economic crisis will reduce the possibility to provide support and subsidies. Furthermore, even in major countries, even relatively rich ones, growing social protests are increasingly suppressed by downright police methods that have always been associated with the harshest forms of authoritarianism. These methods are justified, perhaps quite sincerely, by the need to protect democracy. In reality, however, this is nothing but attempts to protect previous polices and failed elites. In calm conditions, citizens of democratic countries elect their likes, convenient for themselves, which is why the elites have degraded almost everywhere in the old democracies over the past decades. Just compare the leaders of the 1950s-1960s and those of the 2010s. But we must admit that even under stress, people like Churchill or Roosevelt are elected quite rarely. Rightwing or left-wing populists come to power more often.

So, this new, historically perhaps temporary, retreat of democracy, exacerbated by the crisis, poses two difficult challenges to the Russian political class. One is a revision of the conviction, deeply rooted since the decline of the Soviet system, that democracy is always good, free, and satisfying. It is free, but not always: formally, democratic states are often ruled by oligarchies. And it is certainly not satisfying.

\section{Democracy is the result of material well-being, not its cause.}

Another challenge is even more difficult-finding the optimal combination of authoritarian, populist and democratic forms of government for effective development of the country, and spiritual and material well-being of the majority. Standard recipes are not suitable for a large and genetically sovereign power. We will have to go our own way. Growing authoritarian tendencies in the government, which is inevitable during any crisis, are consistent with Russian traditions and current demands, although they do not suit all citizens of modern Russia; nor does the expansion of freedoms-municipal, economic, and 
intellectual. Unlimited political freedom in Russia is fatal, especially in times of crisis. However, there can be no Russian drive without the will. And without it there will be no success. Indeed, in winning wars and in developing giant spaces Russians were guided not only by the "will of the sovereign" but also by their aspiration for freedom, a spiritual impulse. The current almost total pessimism of domestic elites (not yet shared by the authorities) is simply destructive. Clearly, everybody is tired. But then young people have to be pushed forward. However worthy young people will not want to engage in boredom and unfreedom.

It is necessary to reconsider the attitude not only towards modern democracy, but also towards other concepts and theories that came from Europe, the more productive, free and wealthy West. The pandemic crisis has shown that they are ineffective. The nonWest is becoming richer, while in the West modern "liberal political correctness" is destroying the freedom of thought and expression. There is still a large number of economists and political scientists who preach and teach theories and concepts that were born in the Western world for its own needs and that ultimately reflect, for all the (now rapidly narrowing) relative pluralism, the interests of its elites. Most of those theories are not only self-serving, but they are inappropriate for us or completely outdated. In general, the most important challenge exposed by the current crisis is the accelerated erosion of European civilization, which most of our people and even many political antiWesterners consider their own.

The prolonged relative peace generated, above all, by nuclear deterrence, and the growth of well-being, which stopped only recently, have saved the developed countries from the stress characteristic of the entire history of humankind: the need to fight for what is really vital: life, bread, place of habitation, and Homeland. There has been a change in the consciousness of a significant part of Western (and a small part of non-Western) elites and societies. Pseudo-ideologies have started gaining momentum: "democratism" as a semi-totalitarian taboo system; "climatism" as a religion (not to be confused with the necessary concern for environmental protection); individual rights of minorities, but not of societies or the majority; feminism (not to be confused with 
women's rights), LGBT people, Black Lives Matter, Me Too, and so on. A significant part of societies is losing the ideological and spiritual foundations on which humanity has always stood: patriotism, family values, faith.

These shifts were encouraged by elites interested in preserving the status quo they created and that created them. Pseudo-ideologies distract attention from unsolved problems (like growing social injustice), atomize societies, replace normal emotions and values, turn people into robots with programmable reactions, and dehumanize them. Similar, although not as profound, social changes preceded the fall of the Roman Empire and the Republic of Venice, and the Chinese catastrophe of the 18th-19th centuries.

The "decline" of Europe has been talked about for a century. But it seems that now a qualitative watershed has been crossed. In fact, Europe within the European Union is abandoning many of the fundamental European values that have become part of Russia's identity and that we sought to regain after having been partially detached from them for much of the 20th century. The new set of post-European values and ideologies listed above is poisonous, but they are trying to export it.

Russia's pivot to the East, to Asia commenced in the 2010s was quite rational: their markets are more dynamic and the atmosphere there is less hostile. The corona crisis has proved that Asia, authoritarian or outwardly democratic, is much more efficient. The combination of malicious post-European values and disillusionment with the effectiveness of the modernizing potential of Europe/the West calls into question the key, mainly European, identity of most Russians. When substantiating the pivot to the East, its advocates, including myself, were happy to discover Oriental features in Russian social and political traditions. But now we can also talk about questioning the overall cultural and spiritual orientation towards Europe, and our European roots.

\section{The crisis of European civilization is our crisis as well.}

The weakened European elites, having once again talked about strategic independence, are giving it up right away and trying to hide under the United States' wing. There is a new period of the West's short-lived consolidation which coincides with its current decline and 
therefore is its integral part. So far, consolidation is taking place, among other things, through confrontation with Russia. Because the Russian market is smaller, such confrontation is less costly than that with China, which is growing richer. Besides, conflicting with Russia is more familiar. So no major improvement in the deteriorating relations with the European Union should be expected. We will have to cooperate with whoever we can-countries, corporations, universities, people.

\section{CURRENT RISKS}

The period of consolidation will not last long because internal divisions in the United States are too deep, there are problems in the European Union, and interests have diverged far enough. It is all the more important to try in advance to prevent actions aimed at provoking a crisis in relations with Russia in order to maintain intra-European and Atlantic consolidation longer. It is worth remembering that the "missile crisis" of the 1970s was initiated primarily by European elites who were afraid of Washington's strategic withdrawal which would have caused them to lose the American nuclear umbrella and they wanted to keep it by deploying cruise and Pershing missiles. The situation of the 1970s was similar to a crisis both in the West and in Europe. Now the most obvious provocative scenario would be pushing Kiev towards forceful actions. There may be attempts to deploy new destabilizing weapons or step up cyber hysteria.

The almost inevitable extension of multi-level confrontation with the West leaves Russia virtually no alternatives but to continue its rapprochement with Asia and strengthen partnership and the de facto alliance with China, including in the technological field. But it is all the more important to maintain maximum freedom of choice in the political and military fields, and stay away from building any formal unions. It is necessary to go towards the world of the future, towards Asia, not by moving backwards and looking up to the West, but in a conscious and calculated manner. Naturally, this does not require abandoning the European heritage.

The crisis is unfolding amid deep multilateral destabilization of the military-strategic situation due to the use of new technologies 
(fresh examples include drones attacking oil refineries in Saudi Arabia and Armenian targets in Nagorno-Karabakh, or killing an Iranian general). The remains of the arms limitation regimes are falling apart. There is widespread confusion and degradation among elites. There is a growing likelihood of unintentional escalation of multiplying conflicts and desire to use them for distracting attention from snowballing internal problems. The most obvious are the provoking of a crisis around Taiwan, India-China, India-Pakistan, the South China Sea, Iran-Saudi Arabia, Syria, Libya, Central Asia and, of course, Ukraine, and lately also Belarus and the Caucasus. The list goes on.

Impoverishment caused by the economic crisis will lead to internal destabilization in dozens of countries. Many political regimes will start to crumble, including those in Russia's nearest neighborhood.

Preoccupied with their own domestic problems, most of the world's leading countries (except, probably, China, East and Southeast Asia, and partly India) will remain unreliable partners in the medium term. This is also true of the United States and most countries in Europe. Deep engagement with the world of conflicting or falling states and unreliable partners will bring more and more losses and fewer benefits.

\section{NOT RULES BUT BASTIONS}

The duration of the upcoming multi-level crisis, chaos with acute conflicts, and fierce rivalry cannot be predicted-from several years to a decade or longer. But one thing is obvious: one cannot count on longterm foreign policy and foreign economic agreements or sustained success. Failures are likely. One giant failure for all would be the abovementioned escalation to a new world war. Any deep involvement in the emerging extremely volatile and conflicting global environment will lead to smaller-scale aggravations. Physical involvement in such an external world is increasingly becoming a factor of vulnerability. Even tactical gains apparently become impossible or transient. Resourcespolitical, economic, administrative-spent outside the country will be wasted away. In the foreign policy field, Russia should reduce activity in order to avoid major losses, exercise temporary neo-isolationism, and work for a strategic perspective. Foreign policy should no longer 
distract attention from internal revival or cover up the absence of the relevant strategy and policy.

The world will enter a period of struggle not for "new rules" but for military-political, economic, and moral-cultural footholds to be used for establishing these rules (if and when).

For us, the main guidelines for creating such a foothold include mobilizing and strengthening Russian economic power, maintaining effective deterrent potential, and filling national life with meaning as a crucial condition by devising and introducing a new viable offensive ideology for the majority. This ideology should lead forward, recreate the Russian drive and be attractive to the biggest part of the outside world (not just the West, as we tried to do in the past).

A low-cost, but extremely important ideological policy and the development of a new Russian idea corresponding to the demand of society and the world should make up for the necessary partial withdrawal. Such a combination of limited foreign policy neoisolationism (complete may prove destructive) and concentration on domestic economic and ideological recovery and offensive ideological policy will allow Russia to use this crisis as a chance.

The world is faced with the need to develop a system of values based not on the growth of consumption, but on the unity of man and nature, on the fact that a person can achieve respect and self-respect if he serves not only himself, but primarily the family, society, his country, peace, and God. This is a difficult task to fulfil after almost a century of imposed communist and then liberal illusions.

The ailment of the modern world is unprecedented. It seems only a few have so far realized that the pandemic will not help resolve problems and contradictions. On the contrary, it is opening a series of acute crises that will change the entire world. However, studying the past crises and how they were resolved will help the treatment and the selection of proper medicine and practices.

At the end of 2020, there were no signs that the ruling elites of most countries were able to grasp the depth and multidimensional nature of the unfolding crisis. All are trying to get out of the current predicament without making radical corrections to the chartered 
course (especially since such corrections will require a change of elites). So far the opposite has been taking place: the coronavirus pandemic has been used to cover and justify failed politics and old institutions. And yet, in a few years' time we may come to realize that the current crisis was, among other things, cleansing, that it helped push everyone towards normal values and rational policies geared to common benefit. It is important to reach the period of construction stronger, not weaker. And to this end we need to fortify "Fortress Russia" which is potentially open to the world and ready for cooperation and even leadership. A series of upheavals is in store and we must prepare ourselves and our country to face them. 